\title{
On the Temporal Forms in Mordvin
}

Two endings including an $n$-element occur in the declension of Mordvin nominals. These may be called temporal endings. The forms containing these endings appear as temporal verbphrase complements. The first of these endings is Erza ne, Mokša ńc. It is added to the names of the days and seasons as well as to words referring to the time, year or weather conditions; an attribute is usually added to the form. E.g. E kažnyi čine 'каждый день', eŕva v́ene 'каждую ночь', sy godne 'на будущий годъ' (Шахматов, Мордовский этнографическій сборникъ, 780), ṕele ve škane 'um Mitternacht' (Paasonen-Ravila, Mordwinische Volksdichtung I 331), kažnyị burane 'вь каждую бурю' (Шахматов, ib.), M stak šinä. 'an Wochentagen' (Paasonen-Ravila, IV 297), t'ada vieńä 'heute Nacht' (ib. IV 368), kolmâtśä kezânä- 'im dritten Jahre' (ib. IV 86), тя пингоня́ 'в э́то время́' (Мокшанско-русский словарь 208а), l'aftama jakšamńč. 'ilyen hidegben' (Juhász, Moksa-mordvin szójegyzék 42b). Evidently, attempts to distinguish the temporal forms from diminutives based on the basic stem (cf. E tšokšnę, tšokšne 'abends; Abend', Paasonen, Mordwinische Chrestomathie 136) have caused the temporal ń $\varepsilon$-ending to be always stressed in Mokša, no matter what the phonological structure of the word happens to be (Juhász-Erdély, Moksamordvin szójegyzék, Bevezetés 19).

According to the opinion generally held, the Mordvin temporal ending $\mathrm{E}$ ne, $\mathrm{M} \dot{n} \varepsilon$ is a reflex of the old *na, nä locative (Szinnyei, Finnisch-ugrische Sprachwissenschaft² 55, Budenz, Moksa- és erza-mordvin nyelvtan, NyK 13 33, Collinder, Jukagirisch und Uralisch 26; however the Erza na temporal ending is also connected with the Mordvin ne, ne temporal ending), the corresponding forms of which occur in all the other Finno- 
Ugric languages with temporal function. The Mordvin suffix is especially noteworthy of its unique palatal vocalism.

There has been considerable discussion as to whether the old *na, nä locative might also have a reflex with local meaning, specifically in the udalo type adverbs.

In Mordvin the local cases denoting location, separation and motion towards are the inessive $(s o, s e, s a)$, the elative $(s t o, s t e, s t a)$ and the illative (s) (or occasionally the lative $v, \eta$, $j, \eta)$. In certain adverbs different endings are used to express these local relationships. For the case of location a form occurs in which the case ending is solely the final vowel; for the case of separation an ablative in $d o, d^{\prime} e, d a$ occurs (the ablative of the nominal paradigm has no local meaning, the sole exception being in the construction kudodo kudos); for the case of motion towards the lative is used.

Most of these adverbs have a root in $l$ :

$\mathrm{E}$ alo, M ală 'unten, unter', E aldo, M aldă 'von unten her, unter', E alov, alon, M alu 'hinab, herab, nieder, unter' - cf. E M al 'das untere, unten befindliche' (Paasonen, Chrest. 59).

M alula 'lent', M aluldă 'alulról' (Juhász, 25a).

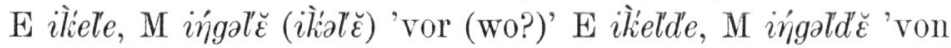
vorn', E ik̀elej, ik̀elev, ił̀ielè, M ingali 'vorwärts, vor (wohin?)' (Paasonen, 65) - cf. M ingal: kud-i. 'tornác' (Juhász, 40a).

E mejle, mäjläa, M melľ̌ 'später, danach, hernach, darauf, nach' (Paasonen, 94).

М ме́коле 'сза́ди, позади́', ме́коли 'сза́ди, позади́; потом, по́сле, в конце́' (Мокшанско-русский словарь 161b).

E ṕele, M ṕcl'̌ 'bei, an', E ṕeld'e, M ṕcl'd'̌ 'von', E ṕelej, ṕelev, ṕeleń, M ṕcli 'zu' - cf. E ṕel', M ṕcl' 'Seite' (Paasonen, 107).

E tombale, M tombal"̌ 'auf der anderen Seite, jenseits', E tombald'e, M tombald' $\breve{\varepsilon}$ 'von der anderen Seite', E tombal'ej, M tombali 'auf die andere Seite, auf jene Seite, über' (Paasonen, 143).

Е товоло, М товола 'там', Е товолдо, М то́волда 'отту́да', Е товолов, М то́волу 'туда́' (Эрзянско-русский словарь 218а, Мокшанско-русский словарь 271b, 272a).

E udalo, M ftală 'hinter (wo?)', E udaldo, M ftaldă 'hinter etwas hervor', E udalov, udalon, M ftalu 'hinter (wohin?)' (Paasonen, 146) - cf. M ftal 'hátsó rész' (Juhász, 38). 
E vasolo 'weit, in der Ferne', E vasoldo 'aus der Ferne' (Paasonen, 151).

Е те-веле 'близко сюда, по сю сторону', те вельде 'поближе отсюда, с этой стороны' (Евсевьев, Эрзянь-рузонь валкс 77).

Е венеле 'на дворе', венельде 'со двора', венелев, венелей, венилив, веньдили, М венели 'на двор' - vrt. Е вениль, веньдиль, М венель 'вне дома, 'на дворе", погода' (Евсевьев, $80)$.

There are also groups with a different kind of stem. Of these only the first one is definitely a reflex of a proto-Mordvin form:

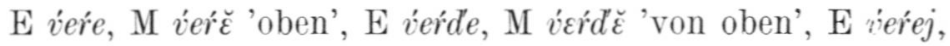
v́erev, verér, M v́cri 'nach oben, in die Höhe' (Paasonen, 153-).

E масторо 'на полу́, на земле́' (Эрзянско-русский словарь 132a), (Bolšaja Tarasovka) mastira 'a földön' (Klemm, Mordvin szövegek [Különlenyomat a pannonhalmi évkönyvbőll 48), (Velikij Vrag) masto•rdo 'von der Diele' (PaasonenRavila, II 388) - cf. E mastor, mastur, mastìr 'Erde' (Paasonen, 93).

M širäa : omba širä 'jenseits' (Paasonen-Ravila, IV 42), fkä šíä 'auf der einen Seite' (ib. IV 27), иирде 'извне́; c' (Мокшанско-русский словарь 305a), širi : omp širi 'auf die andere Seite' (Paasonen, 135) - cf. M šiř̌ 'Kante, Rand, Ufer, Seite; Gegend' (Paasonen, 135).

E jопо : ве ёно 'в стороне' (Евсевьев, 128), оb'еd jono 'im Süden' (Ravila, JSFOu 61 52 52a), kavto jono 'beiderseitig' (Paasonen-Ravila, II 468), ko jono 'in welcher Richtung' (ib. I 480), jondo : те ёндо 'с этой стороны' (Евсевьев, 128), ombot'se jondo 'von der anderen Seite', erva jondo 'von jeder Seite' (Ravila, JSFOu 61 17a), lemibä jonda 'meleg vidékről' (Klemm, 15), jonov : ве ёнов 'в сторону' (Евсевьев, ib.), eŕva jonov 'nach allen Seiten' (Paasonen, 69) - cf. E jon 'Richtung' (Paasonen, 69).

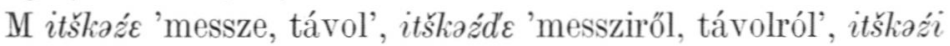
'messze, tova' (Juhász, 41b).

These adverbs have the characteristic feature that the suffix element beginning with a consonant (the suffix of the ablative and prolative - also the ga prolative suffix belong to this class 
of adverbial stems; nevertheless, since these forms are not restricted to the class of adverbs under discussion prolative forms have not been included in the examples) is always added to the consonant stem (thus, for example, also in the $\varepsilon$-stem sire). The stem word can not be distinguished in all cases.

The locative forms have been explained in two ways. Attention has been usually directed to those with $l$ as a derivative suffix.

Budenz brought attention to the fact that the locative forms differ from the corresponding nominative forms as to their final vocalism. He considered the final vowels to have preserved a relic of an earlier suffixal element. Fixing attention on analogous adverbs with ablative formative elements, he decided that the element in question had been a locative ending. Similarly in Finnish locative adverbs essive endings appear parallel with partitive endings (NyK 13 33-, 43). Paasonen held the same view: "Mord. -l- kann ein früheres -ln-vertreten, wie es sicher der Fall ist in solchen Adverb- und Postpositionsformen wie mord. alo 'unten, unter' $=$ fi. alla $<{ }^{*} a l-n a$, tscher. ül-nö id., vgl. mord. al-do 'von unten her' = fi. al-ta; mord. uda-lo 'hinten, hinter': -lo=- fi. Adessivendung -lla $<*$-lna, vgl. mord. uda-ldo 'von hinten her': $-l d o=$ fi. Ablativendung' -lta» (Fi. pellava 'Lein', JSFOu $30_{22} 4$ ). More recently Bubrih has assumed these adverbs to have developed in the following manner: $l n>l, r n>r$ (Историческая грамматика $\S \S 52$, $99,120)$.

If the forms are considered to be old locatives, $n$ must be assumed to have been assimilated into the preceding consonant. Indeed, there are reliable examples of assimilation, but in these cases the preceding consonant has been a sibilant in all cases. The Mordvin inessive is the exact phonological equivalent of the Balto-Finnish and Lappish inessive. In the Mordvin inessive suffix E so, se, M $s a$ the $s$ must have been followed by a consonant in the proto-Mordvin suffix of which the modern variants are reflexes, since $s$ has remained voiceless. This consonant was $n$ which was assimilated into the preceding sibilant (Donner, ASSF 11 486, Setälä, YSÄH 410-, Budenz, Moksa- és erzamordvin nyelvtan, NyK 13 35, Paasonen, Mordwinische 
Lautlehre, MSFOu 22 46-). That it is specifically an element $n$ which is in question is demonstrated by the fact that it has been preserved in some dialects of Erza when the ending was added to a stem ending in $n$ or a sibilant (viz. Paasonen, Chrest. 01 footnote 1 . A similar phenomenon is seen in the śne-inessive suffix of the definite declension which occurs in some Erza dialects [Isakly, Stepnaja Šantala]. That this is a case of the inessive suffix śne added to the selement of the definite declension is demonstrated upon comparison of the źne-allative suffix used in the definite declension of the same dialects with the inessive ending.) In the consonant sequences $n+s n$ and $s+s n$ assimilation has been prevented. The palatal vocalism of the inessive sne, śne endings and of the temporal ne endings is noteworthy. Other examples of loss of postconsonantal $n$ : E viš, M višs, višä 'Spelt', cf. Fi. vehnä, Cher. Biste (Paasonen, Etymologische Streifzüge, FUF 2 186-); E ṕekše, ṕekšę, M

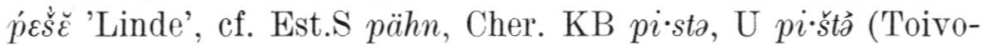
nen, Zur Geschichte der finnisch-ugrischen inlautenden Affrikaten, FUF 19 200, 244). There are, nevertheless, also examples in which this $n$ has been preserved: E kšna, šna, M šna 'Riemen', cf. Fi. hihna, LpL sas̄ne, Cher. šište, cf. Lith. sziksznâ (Paasonen, FUF 2 187-). The following are examples of the same phenomenon: E kšnams, šnams, M šnams 'rühmen, loben, preisen' (Paasonen, Chrest. 136), E ksnau, M snau 'Erbse' (Ravila, JSFOu $61_{3} 33 \mathrm{~b}$, Juhász, 153a). A condition for the preservation of post-consonantal $n$ was that $n$ was the initial element of a stressed syllable. In certain cases the $a$ (perhaps also the $\ddot{a}$ ) of the second syllable had the main stress in protoMordvin (Ravila, Über eine doppelte Vertretung des urfinnischwolgaischen $* a$ der nichtersten Silbe im Mordwinischen, FUF $20105-)$.

There are, however, no examples of the changes $l n>l$, $r n>r$, and a few viewpoints can be given in support of the assumption that a type *udal-no has never existed.

In the examples there was one adverb with an $s$-stem, namely M itškaźz. It cannot be explained as a ${ }^{*} n \ddot{a}$ locative, since $s$ would be expected as the result of assimilation, i.e. the same development which occured in the case of the inessive 
suffix. There is no concrete proof that this adverb is a reflex of a proto-Mordvin form since the data is based only on Mokša evidence. Nevertheless, it is not likely that unproductive suffixes would occur in secondary analogical formations.

It seems apparent that the proto-Mordvin suffixal system did not permit the sequence $n \hat{z}$ in non-initial syllables: all the suffixes of modern-Mordvin which contain an original $n$ are reflexes of a variant no with palatal vocalism: the temporal suffix, the inessive in those cases in which the nasal element has been preserved, the comitative ending nek. Hallap has brought attention to the fact that the verbal derivative elements that contain an $n$ plus vowel and are traceable back to proto-Mordvin presuppose a suffix ńa in the proto-language without a variant $n \hat{z}$ (Hallap, Суффиксы образования глаголов в мордовских языках 18-). (The presence of this $x$ also brings the unusual palatalization of the genetive and allative [? $*_{n}$ lative] to mind.)

In 1945 Ravila stated in Virittäjä that »the form vasolo has no case suffix comparable to the Finnish adessive $(l+n a)$. - _ Evidently the Mordvin adverb _ _ - is a case of an attribute developing into an adverbial" (Nomen verbale suomalais-ugrilaisissa kielissä, p. 157-). These forms are still used as attributes in Erza: vere-pas 'der oben befindliche Gott, der Himmelsgott' (Paasonen, Chrest. 154), alo pel'ej 'hinunter', verée ṕelej 'hinauf' (Paasonen-Ravila, II 331), vije.t' ked' ṕe le ugo lso 'in der Ecke zur rechten Hand' (ib. II 385). Examples of this kind do not, however, offer conclusive proof that forms of the type udalo definitely contain no suffix and are nominative in form, since both nominative and local attributes are possible, i.e. E čej buka 'Sumpfschnepfe, Himmelsziege, Bekassine', moda-numolo 'ein gelbliches Tierchen, Erdhase, Springhase (Dipus)', pakśa-mekš 'Hummel', vir-kudine 'Waldhütte' (Heikkilä, MS. of the Mordvin Dictionary), ведь-эряв 'мифическое существо, живущее в воде (муж ведь-авы)' (Евсевьев, 74), M kud-eŕzj 'házlakó, házban élő' (Juhász, 79b), viiŕ-mat'si 'vadlúd' (Juhász, 202b), moda-numâl = E moda-numolo (Heikkilä, MS.) E kuntškaso sur 'Mittelfinger' (Ravila, JSFOu 61 $1_{3} 35 \mathrm{a}$ ), sęrse-močineń 'meine Körperkräfte' (Paasonen-Ravila, II 
334), mastor-alga kijava 'auf unterirdischem Wege' (ib. III 71). A peculiarity of Mokša is the occurance of the local attribute in a case denoting separation: värdä-täšttnä 'die Sterne droben' (Paasonen-Ravila, IV 33), alda utâmu 'in den unteren Speicher' (ib. IV 12), ftalda kaldazsa 'auf dem hinteren Viehhof' (ib. IV 80), utâmsta tälaf śorânza 'das gedroschene Korn im Speicher' (ib. IV 143), kucta śemjäń raštamga 'damit die Familie im Hause sich mehre' (ib. IV 458). Nevertheless, the possibility of two kinds of attributes has been able to cause the *udal-no type to be replaced by the udalo-type.

The second temporal suffix with an $n$-element is $\mathrm{E} n a$, na, $n d a, d^{\prime} e, n d i, \mathrm{M} n d a, n d \varepsilon$. The suffix $\mathrm{E} n a$, na, M $n d a$ occurs particularly in conjunction with the names of the seasons, but it is also found in words referring to the time of day or to time in general. These forms have attributes in the dialects of Isakly and Kažlytka: E (Malyj Tolkaj) Kiizna 'im Sommer' (Ravila, Ersämordwinisches Wörterverzeichnis, JSFOu 61 29 a), telńa 'im Winter' (ib. 97a), śokśńc 'im Herbst' (ib. 82b), (Isakly) pele ve ška·ñde 'um Mitternacht' (Paasonen-Ravila, I 161), obe.d'ńa ška.ńd'e 'um die Zeit des Mittagsgottesdienstes' (ib. I 320), (Kažlytka) kažnìj ěind'i 'jeden Tag', är čindi 'täglich' (Paasonen, JSFOu 12 149), M t'alânda 'im Winter' (Paasonen, Mordwinische Chrestomathie 141), śokśânda 'im Herbst' (ib. 128), sai-kizinda 'im nächsten Jahre', ilädindä 'abends' (Ahlqvist, Versuch einer Mokscha-Mordwinischen Grammatik 91).

As Bubrih and Hallap have demonstrated the temporal suffix $\mathrm{E} n a, \mathrm{M} n d a$ is a reflex of a proto-Mordvin flectional element which contained the conconant cluster $n d$ plus a vowel. In Erza the reflex of the proto-Mordvin cluster $n d$ is $n$ in noninitial syllables, i.e. M (Reg.) mokšënda, (Paas.) mokšsanda, E (Wied., Paas.) mokšna 'Faust', cf. Cher. KB mâškầndô, U mu•škândâ (Paasonen, Mordwinische Lautlehre, MSFOu 22 41, Hallap, 18, Bubrih, Историческая грамматика $\S ~ 181,152)$. This suffix is seen used in the function of ablativus comparationis in addition to its function as a temporal: M śadând̆ ot'śu, ś. tožd'ع 'nagyobb, könyebb' (Juhász, 144b), śembândă os̀al 'legrosszabb' (ib. 146a). The ablative suffix can be seen 
in the latter part of this ending although use of the ablative in expressions of time is otherwise infrequent (M ṕcl ̌̌-ve škadă 'um die Mitternacht' Paasonen, Chrest. 136, Juhász, 118b). The $n$ element of the ending may be a reflex of the same ${ }^{*} n a, n \ddot{a}$ locative as does the $\mathrm{E} n e, \mathrm{M} n \varepsilon$ temporal suffix. When an $n$ suffix with velar vocalism was not able to be used as such (p. 252), it was expanded with the ablative suffix. Bubrih considered the elements of the suffix to be the locative and ablative suffix (Историческая грамматика, § 182). Beke, too, considered the final element to be an ablative suffix even though he thought the $n$ element strange, possibly a locative suffix (Tavasz, NyK $40463-$ ). Lakó connects this Mordvin suffix with the prosecutive suffix of the Permian languages and the $d$-element of the Hungarian adverbs ide, oda (Permi prosecutivusrag és transitivusrag rokonnyelvi megfelelöi, NyK 53 20; but viz. Erkki Itkonen's criticism FUF 32 Anz. 64).

The third temporal suffix, $t, t^{\prime}$ appears in Erza and Mokša. Forms inflected with this suffix occur as verb phrase complements. The suffix is used particularly in names denoting time of day. An attribute may be added to the form: E čit' 'bei Tage' (Paasonen-Ravila, III 191), tšsokśt' pozda 'spät abends' (ib. II 422), tečä v́ät' 'in dieser Nacht' (ib. III 302), sịred'meń ṕel't' 'in ihren alten Tagen', taštumań ṕel't' 'im Alter' (ib. I 209), M tä v'et' 'heute nacht' (ib. IV 269), šit' 'am Tage' (ib. IV 528), ilä·t' 'am Abend' (ib. IV 824), ilä·nń zarat 'bei der Abendröte' (ib. IV 751), śirod’oń ṕäl'ct' 'in ihren alten Tagen' (ib. IV 383), ombâtsä vremat' 'ein anderes Mal' (ib. IV 859), ombit 'übermorgen', yotai-kizit 'im vorigen Jahre', sai-kizit 'im nächsten Jahre' (Ahlqvist, 91).

Lakó connects this temporal suffix with the transitive suffix of the Permian languages and the locative suffix of the Ugric languages (NyK 53 21-).

In Mordvin, however, there are other form-classes with $t$-endings.

There is one prepositional construction in Mordvin. In it a preposition in the lative is followed by the main word which is inflected with the suffix $t$. The construction occurs as a verbal complement: E sitt' alov pant 'kamen bergab (gefahren)' (Paa- 
sonen-Ravila, III 310), mon tịk kise käpid'ija vérev menel't te norov-avant' 'für euch habe ich dieses Getreide hoch gegen den Himmel gehoben' (ib. III 103), M vä̈ri meñal't ḱ kepad'ams / alu mastarct vačkad’ams 'um (mich) gegen den Himmel droben zu heben, um (mich) gegen die Erde unten zu schlagen' (ib. IV 462), väríi vedńat son ujaź tuś 'sie begann stromaufwärts zu rudern' (ib. IV 48).

The third type is connected to the preceding insofar as it has two components and the first of them is probably a lative adverb. Another adverb is also possible and often the third participle or an adjective is the first component. The second component, ending in $t$, is the name of a part of the body. The construction occurs as a verb phrase complement. Its semantic equivalent in Finnish and Lappish is the nominativus absolutus: Е мәйгәнээ́ḿ 'наотмашь' (Bubrih, § 98), p u l'

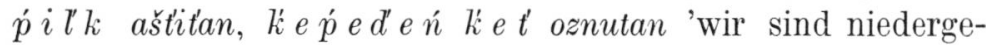
kniet, wir flehen mit erhobenen Händen' (Paasonen-Ravila III 19-), moń babań latsa $p a n ́ z ̌ i n ́ k u r k t$ kor'tä 'Sie sprach (Prs.) wie meine Grossmutter mit offenem Munde' (ib. III 304), M kars̆̀zk końat 'ellen, szembe' ("szembe homlokkal») (Juhász, 54a), ko má̌a ń pŕat suva·mga 'deswegen, weil ich mit verhülltem Kopf - - gehen muss' (Paasonen-Ravila, IV 457),

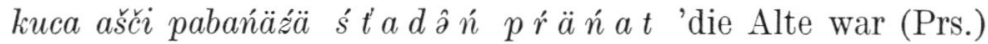
in der Stube erhobenen Hauptes' (ib. IV 385), mest' jakat ton

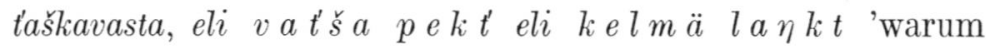
gehst du bis so weit umher? Oder (gehst) du wegen hungrigen Magens oder frierenden Körpers' (ib. IV 855).

It seems quite certain that the element in the suffix is the plural suffix $t$. It occurs in Mordvin as the case of both the plural subject and object.

In the type vat'śa pekt', leped'en liet' the suffix may be the $t$ of the nominative in which case there would be an example of the Mordvin nominativus absolutus construction.

In the construction alov pant the latter part is evidently the reflex of an earlier verbal complement, an example of the accusativus viae which is also found in other Finno-Ugric languages. Also in Lappish the accusativus viae occurs dialectally primarily only in conjunction with a lative adverb.

The accusativus temporalis does appear in Finno-Ugric lan- 
guages as a verbal complement. (Paavo Siro, Suomen kielen lauseoppi 1.37 and Eeva Kangasmaa-Minn, Verbi- ja objektikategorioiden keskinäisistä suhteista, Sananjalka 10 p. 56 are of a different opinion: they classify the so called object-type time qualifier in Finnish as a verb phrase complement.) But at least in Lappish and Cheremis this is also used as a verb phrase complement: LpL nåv jut mån muhteem ijaait ittjiv nuola piktasijt 'so that I didn't take clothes off on some nights' (Pirak, Jåhtee saamee viessoom, 29), Cher. tudo šažam nalan sösnam 'he bought pigs in the autumn' (Eeva KangasmaaMinn, Tšeremissin kaksoisobjekti, Acta Universitatis Tamperensis A: 2655 ). It is probably not impossible to see the $t$ of the plural in the Mordvin $t^{\prime}, t$ temporal ending, an opinion expressed by Wiedemann in his time (Grammatik der erzamordwinischen Sprache 46).

In regards to palatalization the temporal usually differs from the nominative plural, cf. M (C V) v́et' 'éjjel', vet 'éjszakák' (Juhász, 198b), E Kažlytka väat' tempor., ṕet plur. < ṕe 'Ende' (Paasonen, MSFOu 2248 ). And Sahmatov is of the opinion that the ending of the temporal is $t^{\prime}(779-)$. In the Paasonen - Ravila texts, however, the palatalized type is not the only one. 